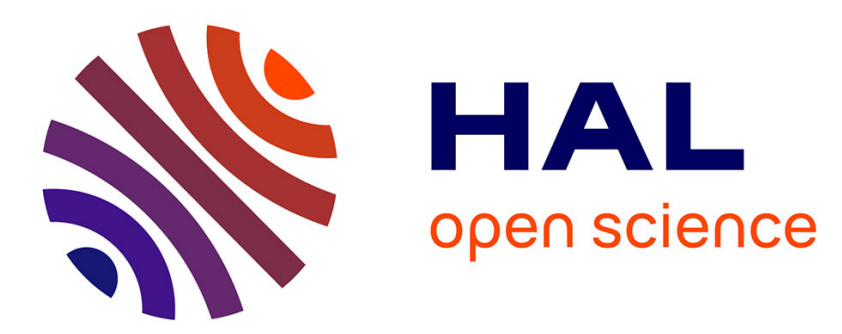

\title{
Properties of small aggregates of group VI elements (S, Se, Te). Evidence for metallic character of tellurium aggregates
}

\author{
A. Hoareau, B. Cabaud, R. Uzan
}

\section{- To cite this version:}

A. Hoareau, B. Cabaud, R. Uzan. Properties of small aggregates of group VI elements (S, Se, Te). Evidence for metallic character of tellurium aggregates. Journal de Physique Lettres, 1978, 39 (17), pp.303-305. 10.1051/jphyslet:019780039017030300 • jpa-00231503

\section{HAL Id: jpa-00231503 https://hal.science/jpa-00231503}

Submitted on 1 Jan 1978

HAL is a multi-disciplinary open access archive for the deposit and dissemination of scientific research documents, whether they are published or not. The documents may come from teaching and research institutions in France or abroad, or from public or private research centers.
L'archive ouverte pluridisciplinaire HAL, est destinée au dépôt et à la diffusion de documents scientifiques de niveau recherche, publiés ou non, émanant des établissements d'enseignement et de recherche français ou étrangers, des laboratoires publics ou privés. 


\title{
PROPERTIES OF SMALL AGGREGATES OF GROUP VI ELEMENTS (S, Se, Te). EVIDENCE FOR METALLIC CHARACTER OF TELLURIUM AGGREGATES
}

\author{
A. HOAREAU, B. CABAUD and R. UZAN \\ Université Claude-Bernard, Lyon-I, Département de Physique des Matériaux, L.A. 172, \\ 43, boulevard du 11-Novembre-1918, 69621 Villeurbanne Cedex, France
}

(Reçu le 5 juin 1978, accepté le 10 juillet 1978)

\begin{abstract}
Résumé. - On a mesuré les potentiels d'ionisation ainsi que les énergies d'atomisation d'agrégats de tellure $\operatorname{Te}_{n}(2 \leqslant n \leqslant 7)$. Le comportement des éléments de la colonne VI est examiné et conduit à penser que le tellure se distingue nettement du soufre et du sélénium.
\end{abstract}

\begin{abstract}
Ionization potentials and atomization energies of $\mathrm{Te}_{n}$ aggregates $(2 \leqslant n \leqslant 7)$ have been measured. The investigation of the behaviour of elements of group VI lead to the conclusion that tellurium is very different from sulphur and selenium.
\end{abstract}

During the past years, a great deal of work has been published about small aggregates of noble or transition metals $[1,2,3]$. Few results are available concerning aggregates of group VI. However, the elements of this column present a great diversity of character and are commonly used in the semiconductor industry. The aim of this communication is to give for the first time, as far as we are aware, the ionization potentials of $\mathrm{Te}_{n}$ with $2 \leqslant n \leqslant 7$ and to make a comparison between aggregates of sulphur, selenium and tellurium.

The method used to study these aggregates is the same as that used previously by us [4]. The substance is put into a Knudsen cell which is heated by radiation from encircling filaments. The material effusing from a hole drilled in the top of the cell is collimated by a set of diaphragms and the resulting molecular beam enters the ionization chamber of a mass-spectrometer where it can be analysed. The ionization source uses the retarding potential difference (RPD) method and permits precise measurements of ionization potentials. The only improvement is an automation of our apparatus and the adoption of a counting technique which has increased the sensitivity of the apparatus. Thus measurements of very low intensity species have been possible. Figure 1 gives an example of experimental ionization efficiency curves for $\mathrm{Te}_{6}$ and $\mathrm{Te}_{7}$. As can be observed in table $\mathrm{I}$, these species represent respectively $5 \times 10^{-3}$ and $5 \times 10^{-4}$ of the total vapour pressure: Great care has been taken in the choice of crucible material to prevent chemical

\section{TABLE I}

Relative ion intensities $\left(\mathrm{Te}_{2}^{+}=100\right)$ with an electron energy of $11 \mathrm{eV}$ at a temperature of $730 \mathrm{~K}$.

$\begin{array}{cccccccc}\text { Vapor species } & \mathrm{Te}^{+} & \mathrm{Te}_{2}^{+} & \mathrm{Te}_{3}^{+} & \mathrm{Te}_{4}^{+} & \mathrm{Te}_{5}^{+} & \mathrm{Te}_{6}^{+} & \mathrm{Te}_{7}^{+} \\ - & - & - & - & - & - & - & - \\ \text {Intensity } & 0.44 & 100 & 1.76 & 0.05 & 9.18 & 0.5 & 0.05\end{array}$

interactions with the element studied. We have also used a double oven assembly with which it is possible to modify the relative proportions of species present in the vapour, and to carry out thermodynamic investigation of the vapour leading to the determination of atomization energies of the aggregates.

The atomization energy of the aggregate $\mathrm{X}_{n}$ refers to the following reaction :

$$
\mathrm{X}_{n} \text { (gas) } \rightarrow n \mathrm{X} \text { (gas) }
$$

where all reactants and products are in their electronicvibràtional-rotational ground states and possess no relative kinetic energy. It is equal to the standard enthalpy change $\Delta H_{0}^{0}$ in reaction (1) at $0 \mathrm{~K}$.

This quantity cannot be directly measured, but is obtained by combination of the enthalpy change of equilibrium reactions such as :

$$
\mathrm{X}_{n} \text { (gas) } \leftrightarrows \frac{n}{2} \mathrm{X}_{2} \text { (gas) }
$$

with the dissociation energy of the dimer which is generally known. 


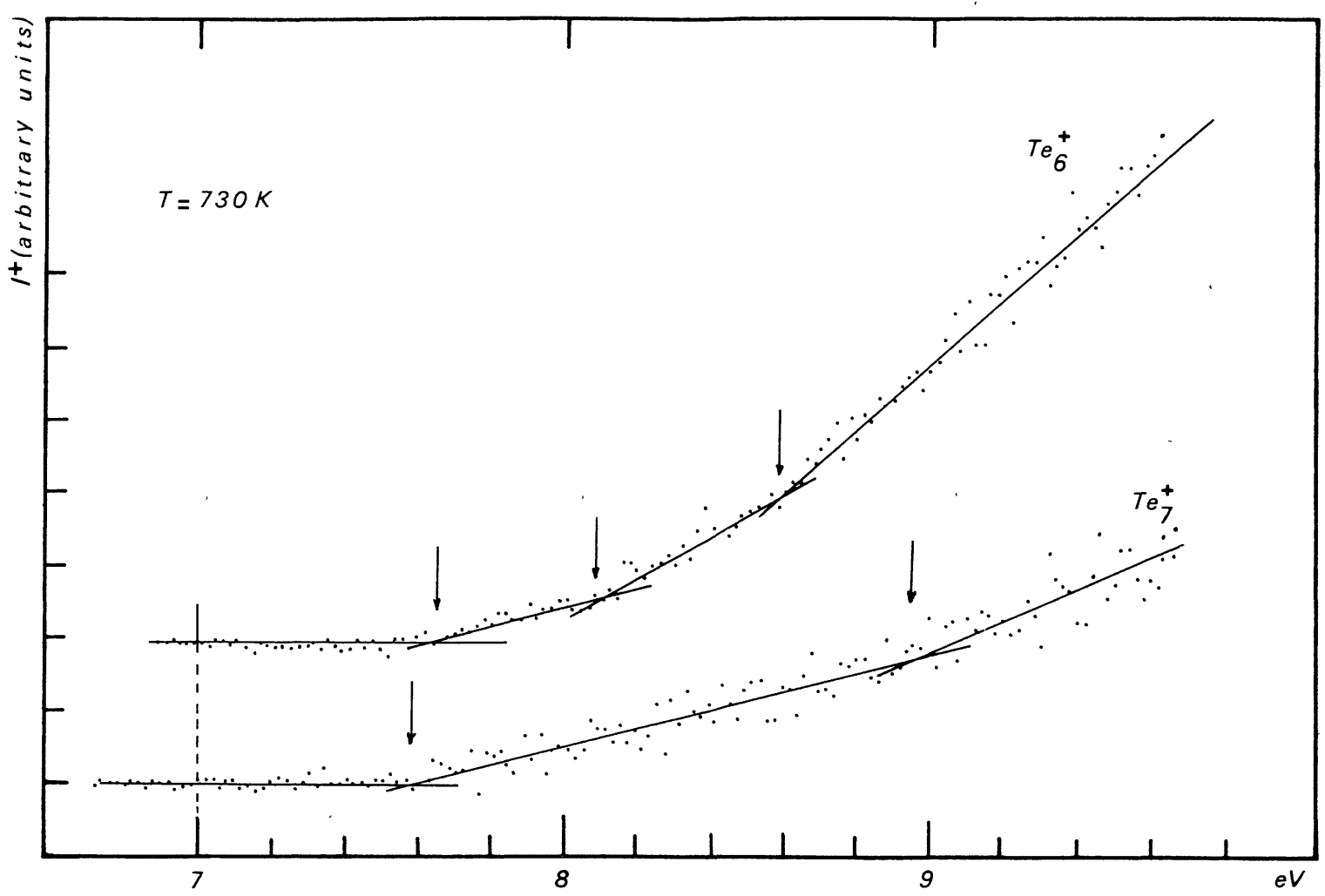

FIG. 1. - Ionization efficiency curves of $\mathrm{Te}_{6}^{+}$and $\mathrm{Te}_{7}^{+}$.

The ionization potentials obtained for $\mathrm{Te}_{n}$ aggregates are presented in table II and figure 2 shows experimental ionization potential variations versus size of aggregates for selenium and tellurium. The noticeable point is the great difference between the two curves. In the case of selenium, the aggregates are separated in two groups, whose mean potentials are separated by about $1 \mathrm{eV}$. For tellurium this separation

\section{TABLE II}

Ionization potentials of $\mathrm{Te}_{n}$ aggregates.
Aggregate

$\mathrm{Te}_{2}$
$\mathrm{Te}_{3}$
$\mathrm{Te}_{4}$
$\mathrm{Te}_{5}$
$\mathrm{Te}_{6}$
$\mathrm{Te}_{7}$

$\mathrm{Te}_{2}$

$\mathrm{Te}_{3}$

$\mathrm{Te}_{5}$

$\mathrm{Te}_{6}$

$\mathrm{Te}_{7}$
Ionization potential in $\mathrm{eV}$

$8.16 \pm 0.08$

$7.39 \pm 0.08$

$8.07 \pm 0.1$

$7.54 \pm 0.08$

$7.75 \pm 0.1$

$7.64 \pm 0.1$

does not exist but the ionization potentials exhibit alternations. For sulphur we can refer to the results of Berkowitz [5] which are similar to those we have found for selenium. So it seems that aggregates of sulphur and selenium present great similitude but those of tellurium are essentially different. To explain this typical behaviour we have carried out calculations in the framework of the CNDO method. In the case of selenium we have shown in a preceding paper [6]

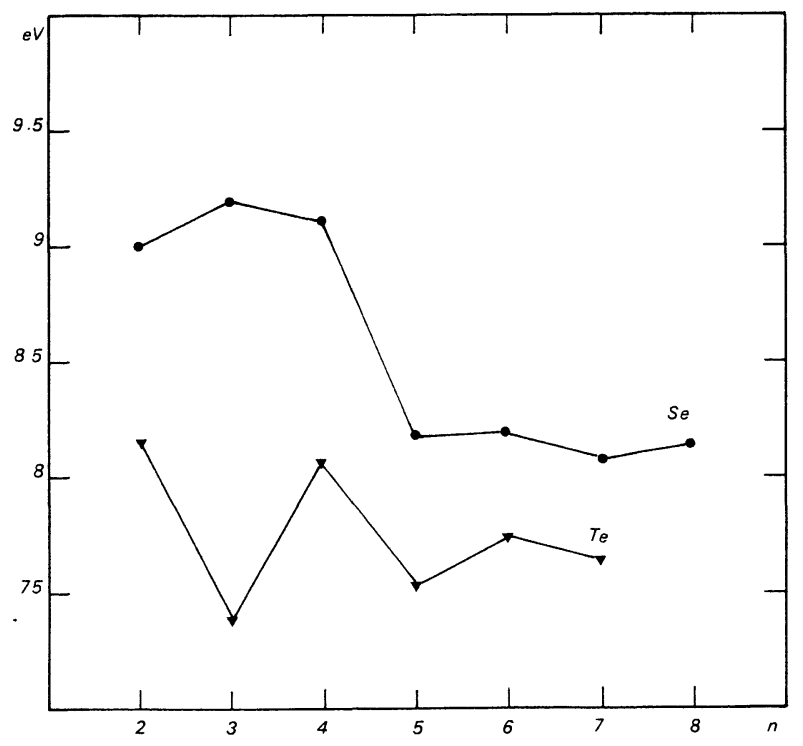

FIG. 2. - Experimental ionization potential variations versus size of aggregates for selenium and tellurium.

that the break which appears on the ionization potential curve seems to be connected directly to the intervention of the $4 \mathrm{~d}$ virtual orbital. For tellurium the alternations of the ionization potentials cannot be understood in terms of hybridization but are connected with the structure of the aggregates. Indeed, structural data and other electronic properties are inconsistent with the existence of independent chains in the liquid 
state of tellurium. Cabane and Friedel [7] have proposed that the local order consists of sites with 2 or 3 first neighbours, joined by bonds with a strong covalent character. Using this hypothesis we have carried out calculations which give a curve of ionization potentials very close to the experimental one. Details will be given in a forthcoming paper. This result confirms the metallic character of tellurium aggregates where interatomic bonds between chains are as quite strong as intraatomic ones in a chain, whereas selenium can be considered às a set of independent chains. The second comparison which can be made concerns the stability of the aggregates. Figure 3 represents the atomization energies per atom as a function of the size of the aggregates. We see that the stability increases quickly with the size and then becomes nearly constant. It is to be noted that if stability is defined as atomization energy per atom then $\mathrm{Te}_{6}$ is more stable than $\mathrm{Te}_{5}$ although $\mathrm{Te}_{5}$ is much more abundant in tellurium vapour. Sulphur and selenium systems display a similar curve that seems typical of group VI. It is noticeable that the asymptotic value of the curves for $\mathrm{S}$ and Se is very close to the cohesive energy of the bulk (dotted lines of fig. 3). In the case of tellurium the curve reaches a limiting value quite different to the cohesive energy of the metal but close to that of the liquid $(1.8 \mathrm{eV})$. This can be regarded as a confirmation that the structure of tellurium aggregates is not similar to the structure of

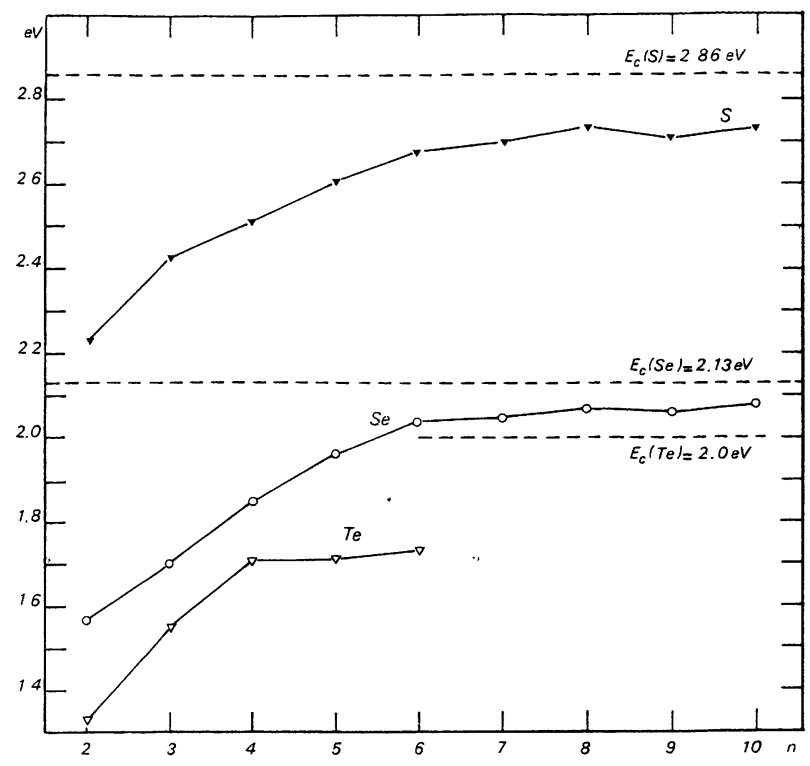

FIG. 3. - Atomization energy per atom of aggregates of group VI as a function of the size of the aggregates.

the solid, but to that of liquid tellurium which is metallic.

The results show that for elements of group VI, sulphur and selenium give quite similar aggregates but that tellurium aggregates are more compact and have a metallic structure.

\section{References}

[1] Baetzold, R. C., J. Chem. Phys. 55 (1971) 4355 and 4363; J. Chem. Phys. 62 (1975) 1513.

[2] Messmer, R. P., TuCKer Jr., C. W. and Johnson, K. H., Chem. Phys. Lett. 36 (1975) 423.

[3] Jones, R. O., Jennings, P. J. and Painter, G. S., Surf. Sci. 53 (1975) 409.
[4] Hoareau, A., Ph. D. University Claude Bernard, Lyon I (1977).

[5] Berkowitz, J. and Lifshitz, J. Chem. Phys. 48 (1968) 4346.

[6] Hoareau, A., Joyes, P., Cabaud, B. and Uzan, R., Surf. Sici. 57 (1976) 279.

[7] Cabane, B. and Friedel, J., J. Physique 32 (1971) 73. 